\title{
INFLUENCE OF CHANGE IN THE PROPORTION \\ OF H1 HISTONE VARIANTS ON MICROSPOROGENESIS AND DEVELOPMENT OF MALE GAMETOPHYTE IN TRANSGENIC PLANTS OF TOBACCO (NICOTIANA TABACUM L.)
}

\author{
JoANNA ŚluSARCZYK ${ }^{1}$, ANDRZEJ WIERZBICKI ${ }^{2}$, MARCIN PRZEWŁOKA ${ }^{2}$, \\ TERESA TYKARSKA ${ }^{3}$, ANDRZEJ JERZMANOWSKI ${ }^{2,4}$, MIECZYSŁAW KURAŚ ${ }^{3}$ \\ ${ }^{1}$ Department of Ecology and Environmental Protection, Swietokrzyska Academy \\ Swietokrzyska 15, 25-406 Kielce, Poland \\ ${ }^{2}$ Laboratory of Plant Molecular Biology, Warsaw University \\ Pawinskiego 5a, 02-106 Warsaw, Poland \\ ${ }^{3}$ Department of Plant Morphogenesis, Warsaw University \\ Miecznikowa 1, 02-096 Warsaw, Poland \\ ${ }^{4}$ Institute of Biochemistry and Biophysics, Polish Academy of Sciences \\ Pawinskiego 5a, 02-106 Warsaw, Poland
}

(Received: May 17, 2002. Accepted: September 4, 2002)

\begin{abstract}
As continuation of investigations in to the mechanism of the role of the $\mathrm{H} 1$ histone, which is a crucial protein component chromosomes of all eukaryotes, transgenic tobacco plants with different levels of the H1 histone variants were examined. Tobacco has six sequential variants of the $\mathrm{H} 1$ histone: two major ones (H1A and H1B), constituting ca. $90 \%$ of all $\mathrm{H} 1$, and four minor ones (H1C, H1D, H1E and H1F), occurring in very small quantities. The following groups of plants were examined: $\mathrm{K}$ - control group with a full set of histone variants; $-\mathrm{AB}-$ with the $A$ and $B$ variants removed; $-\mathrm{ABCD}$ - with the A, B, C and D variants removed; and -CD - with the $\mathrm{C}$ and $\mathrm{D}$ variants removed. The analysis of microsporogenesis in those plants, based on preparations squeezed in acetoorcein, revealed the asynchronous course of meiosis in $-\mathrm{AB}$ and $-\mathrm{ABCD}$ plants, occurrence of chromosomal aberration, and, consequently, the formation of sterile pollen grains (accordingly: $84,4 \%$ and $81,4 \%$ ). In $-\mathrm{CD}$ plants, the percentage of aberration and sterile pollen grains was similar to the control material. Electron microscope observations of microsporogenesis showed ultrastructural changes. In - AB and - ABCD plants, a major portion of the pollen grains were degraded. The smallest number of degraded pollen grains, in comparison with the control, was found in the $-\mathrm{CD}$ group.
\end{abstract}

KEY WORDS: Nicotiana tabacum L., histone H1 variants, microsporogenesis disorders, sterile pollen grains.

\section{INTRODUCTION}

The role of the H1 histone, which is one of the main structural proteins of chromatin in the course and regulation of cellular processes has not yet been thoroughly studied. Investigations of transgenic tobacco plants (Prymakowska-Bosak et al. 1996, 1999) have confirmed the presumption that this protein can participate in specific regulation of the expression of particular genes and that it does not act as a general repressor of transcription. The H1 histone occurs in plant and animal cells in the form of sequentially different variants. There are six such variants in tobacco: two major ones (H1A and H1B), which constitute ca. $90 \%$ of all H1, and four minor ones (H1C, H1D, $\mathrm{H} 1 \mathrm{E}$ and H1F), occurring in very small amounts. Experimental reduction of the level of the main $\mathrm{H} 1$ variants in tobacco, combined with elevated levels of its small variants, has caused various phenotypic changes (Prymakowska-Bosak et al. 1999). No influence on vegetative development and differentiation of plants has been observed; however, disturbances in the normal course of meiosis in anthers occurred, causing the formation of sterile pollen grains (Prymakowska-Bosak et al. 1999; Ślusarczyk et al. 2001a, 2001b). Two minor variants, H1C and H1D, the level of which rose after the reduction of the levels of the two major $\mathrm{H} 1$ variants, are highly homologous to the $\mathrm{H} 1$ variants 
induced by drought stress. Their induction caused by a shortage of water was studied in tomato (Wei and O'Connel 1996) and in Arabidopsis (Ascenzi and Gantt 1997). The rise in their levels in Arabidopsis indicates the existence of various intranuclear mechanisms for separating the major H1 histone variants, which suggests their role in regulating specific sets of genes (Ascenzi and Gantt 1999). Thus, the function of particular variants of the H1 histone in the normal physiology of plants and organisms has not yet been fully explained.

As a continuation of our studies on the function of the $\mathrm{H} 1$ histone, we construed transgenic plants characterised by a lack of expression of the two major $(\mathrm{A}, \mathrm{B})$ and two minor (C, D) variants of H1. This work presents an analysis of the process of microsporogenesis and the formation of the male gametophyte in those plants (without a description of the wall layers and tapetum), as they are affected by the most important changes induced by under-expression of the examined variants of the $\mathrm{H} 1$ histone.

\section{MATERIAL AND METHODS}

The following groups of transgenic tobacco (Nicotiana tabacum L.) plants were investigated: a control group with a full set of the histone variants $(\mathrm{K})$, a group with $\mathrm{A}$ and $B$ variants set out $(-A B)$, a group with $A, B, C$ and $D$ variants set out $(-\mathrm{ABCD})$ and with $\mathrm{C}$ and $\mathrm{D}$ variants set out $(-C D)$. The methods for obtaining and cultivating the plants, as well as their morphological and molecular characteristics, have been discussed in the work of Przewłoka et al. (2002).

The subsequent developmental stages of pollen in the control plants, correlated with the length of the flower buds, have been defined using squashed preparations in acetoorcein (a detailed description of making the preparations is set forth in the work of Ślusarczyk et al. 2001a). On this basis, the following stages were distinguished: early archesporial (5 mm-long buds), archesporial (6 mm-long buds), early meiotic ( $7 \mathrm{~mm}$-long buds), older meiotic ( 8 mm-long buds), tetrad ( $9 \mathrm{~mm}$-long buds), microspore (10 mm-long buds), vacuolated microspores (14 mm-long buds), immature pollen grains (16 mm-long buds), and mature pollen grains (fully-blown flowers, 45-mm long). In plants with various levels of H1 histone variants, similar stages were distinguished, with the exception of meiotic stages, which were combined into a single meiotic stage, due to their asynchronous course.

Ultrastructural changes in microsporogenesis of the examined groups of plants were analysed using a transmission electron microscope (TEM). Anthers of subsequent developmental stages were fixed for 2 hours in $2 \%$ glutaraldehyde of $\mathrm{pH} 7.2$ ( $0.1 \mathrm{M}$ cacodylate buffer). The material was subsequently postfixed for 2 hours in $2 \% \mathrm{OsO}_{4}$, dehydrated in ethanol and, through propylene oxide, embedded in the Epon/Spurr mixture of epoxide resins. Ultrathin transections $( \pm 80 \mathrm{~nm})$ were cut with a LKB microtome (Sweden), then contrasted in saturated water solution of uranyl acetate (30 min) and lead citrate (30 min) according to Reynolds (1963). The preparations were observed in a JEOL JEM1200EX transmission electron microscope at voltage of 90 $\mathrm{kV}$. Electronograms were made according to the classical photographic method, using Kodak negative films.
The vitality of pollen grains was examined by staining with a $1 \%$ solution of 2,3,5-tetrazolium chloride in 0.15 M TRIS-HCl at pH 7.8 (Stanley and Linskens 1974). Unstained pollen grains were treated as dead.

Phase indices of meiosis and aberrations were examined using a Nikon light microscope on the basis of squashed preparations in acetoorcein. Calculations were made for 1000 cells per each of the ten preparations and repeated for 5 different plants from each combination.

\section{RESULTS}

\section{Control plant}

Early archesporial stage ( $5 \mathrm{~mm}$-long bud)

In a cross section of an anther from a $5 \mathrm{~mm}$-long flower bud, four future pollen sacs were developed as distinct thickenings. In each sac, the epidermis and several sub-epidermal layers of a meristematic type could be distinguished. The cells of the archesporial tissue were polyhedral and closely packed. Between the neighbouring cells, plasmodesmal junctions were visible (Fig. 1, arrows). The cells contained dense cytoplasm with numerous, evenly distributed mitochondria and ribosomes, scarce and short rER cisternae and Golgi structures. Their large nuclei in the cells of the other layers, had dispersed chromatin and active nucleoli.

\section{Archesporial stage (6 mm-long bud)}

At this stage, inside the pollen sac, sporogenous tissue was formed, in a croissant-like shape. Polyhedral cells of the tissue were still closely packed and were enveloped in a thin cell wall with plasmodesmata (Fig. 2, arrows). The most important difference, in comparison to the previous stage, was their entering into the early meiotic prophase (zygotene) (Fig. 2). The chromosomes resembled thin threads, characteristically concentrated in one pole of the nucleus, forming the bouquet stage. The dense cytoplasm of sporogenous cells still contained numerous oval mitochondria, long plastids with starch grains and rough ER cisternae.

\section{Early meiotic stage ( $7 \mathrm{~mm}$-long bud)}

The meiocytes of this stage were distinctly separated by a dense layer of callose; the plasmodesmal junctions between them had disappeared. The meiocyte nucleus was surrounded by a folded nuclear envelope and contained despiralised chromosomes at the diplotene stage of prophase I (Fig. 3). Their cytoplasm contained an even distribution of small vacuoles and numerous organelles of a typical appearance.

\section{Older meiotic stage ( $8 \mathrm{~mm}$-long bud)}

In the stamen of an $8 \mathrm{~mm}$-long bud, the meiocytes were still surrounded by a thick layer of callose. The meiotic division was synchronised, $80 \%$ of the meiocytes were at the metaphase stage of the first division, and the remaining ones in the prophase and anaphase. In comparison with the previous stage, the density of the meiocyte cytoplasm increased. Depending on the phase of the meiotic division, the locations of mitochondria, plastids and small vacuoles changed. In the metaphase, the organelles were located around the karyokinetic spindle (Fig. 4), and during the 

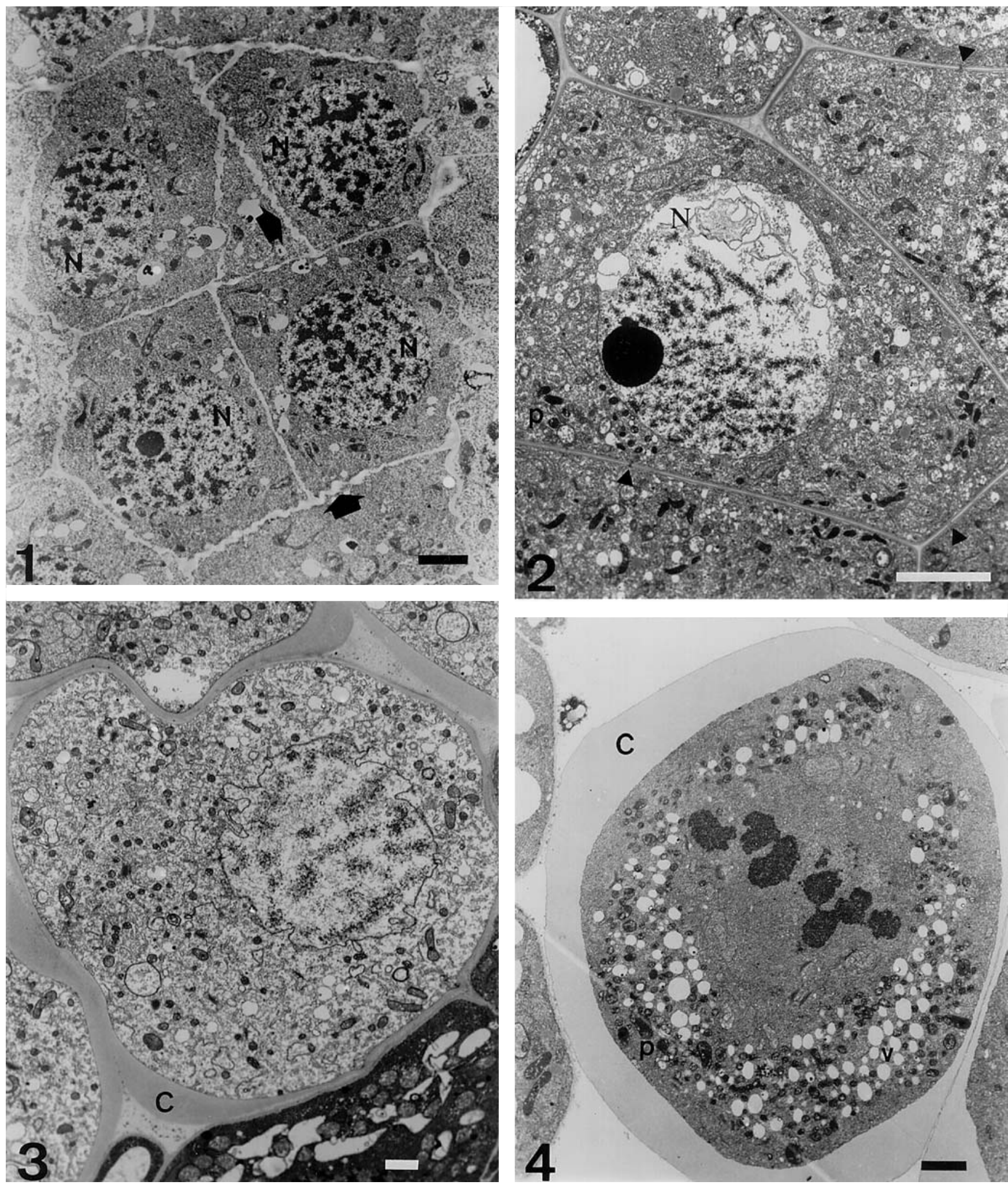

Figs 1-4. Microsporogenesis in control plants. Bars $=1 \mu \mathrm{m}$.

Fig 1. Control plants archesporial tissue's cells.

Fig. 2. First meiotic prophase in the sporogenous cell. Chromosomes build a characteristic bouquet stage, $\mathrm{C}-$ callose.

Fig. 3. A meiocyte in the I meiotic prophase (diplotene) surrounded by callose. In the cytoplasm there are many organelles.

Fig. 4. Metaphase I of meiotic division. Organelles are placed around the kariokinetic spindle.

first telophase, they moved to the equatorial plane, resembling the cell plate, which forms during simultaneous cytokinesis.

\section{Tetrad stage (9 mm-long bud)}

The pollen sacs were filled with microspore tetrads surrounded by a thick callose wall (Fig. 5). The microspores had a large centrally located nucleus. Their dense cyto- 

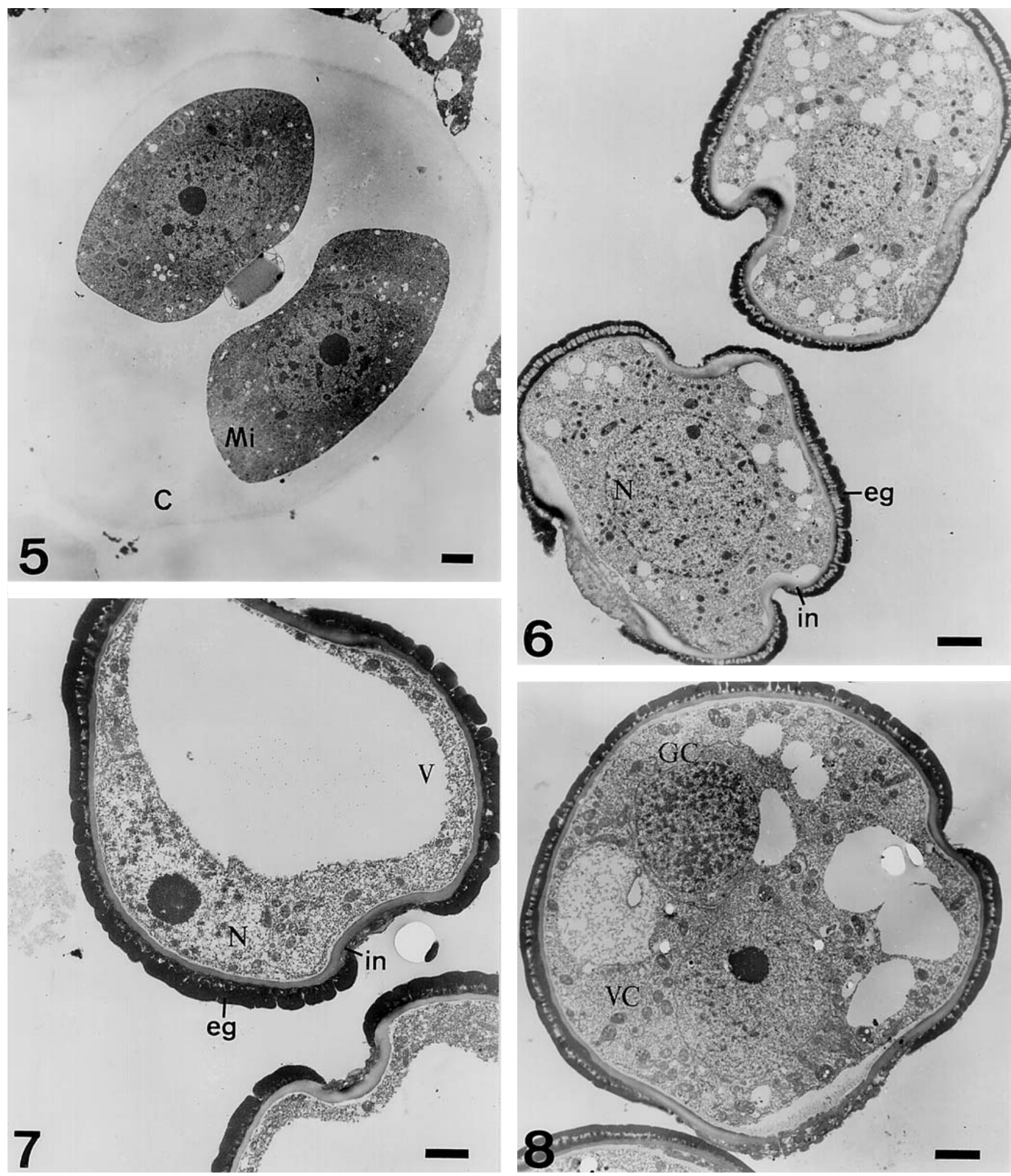

Figs 5-8. Tetrads, microspores and pollen grain in control plants. Bars $=1 \mu \mathrm{m}$.

Fig. 5. Two of the four microspores that make up the tetrad surrounded by a common callose (C) envelope.

Fig. 6. Onenuclear microspores surrounded by sporoderm: exine (eg) and intine (in).

Fig. 7. A microspore with a big central vacuole (v) surrounded by a regularly formed sporoderm. A parietal microspore's nucleus is visible.

Fig. 8. Pollen grains of the control plant. A vegetative (VC) and generative (GC) cells are visible.

plasm contained small vacuoles, short rER cisternae, plastids with dark matrix, and lipid bodies (Fig. 5). On the surface of the microspores, the sporoderm had not yet began to form.

\section{Microspore stage (10 mm-long bud)}

At this stage, callose was hydrolysed and microspores were loosely packed in the stamen sac. They were surrounded by a typical sporoderm, homogeneous in their whole 
surface (with distinct exine and intine layers), with four typical pores (Fig. 6). The microspore nucleus was located centrally in rarefied cytoplasm, containing a few mitochondria, plastids and small vacuoles.

\section{Vacuolated microspores stage (14 mm-long bud)}

This stage was characterised by microspore vacuolation. Many small vacuoles merged to form large central vacuoles, pushing the nucleus towards the cell wall (Fig. 7). Their cytoplasm contained plastids, mitochondria and rough ER. The microspores were surrounded by sporoderm of a typical homogeneous structure, with distinct exine and intine layers.

\section{Immature pollen grains stage (16 $\mathrm{mm}$-long bud)}

In vacuolated microspores, the nucleus, located close to the cell wall, had undergone mitotic division, leading to formation of a pollen grain consisting of a vegetative cell and a parietally located generative cell. The organelles were concentrated around the nucleus of the vegetative cell. In its cytoplasm small vacuoles were also observed. Pollen grains were surrounded by a typically formed sporoderm. The exine and intine evenly enveloped the surface of the pollen grain. Inside the pollen sac, vacuolated microspores, which had not yet undergone the first mitotic division, were occasionally found.

\section{Mature pollen grains stage (45-mm long fully-blown flower)}

The fully shaped pollen grains had undergone the process of maturation, reaching the stage of mature male gametophytes. The generative cell had been separated from the sporoderm and immersed in the cytoplasm of the vegetative cell (Fig. 8), within which numerous mitochondria and plastids filled with starch and rough ER were visible. Among normal pollen grains few undeveloped ones were found; those grains degenerated. They were wrinkled, had an irregular shape and a markedly degraded protoplast. They constituted $8 \%$ of the pollen grains observed in the control (Diagram 1).

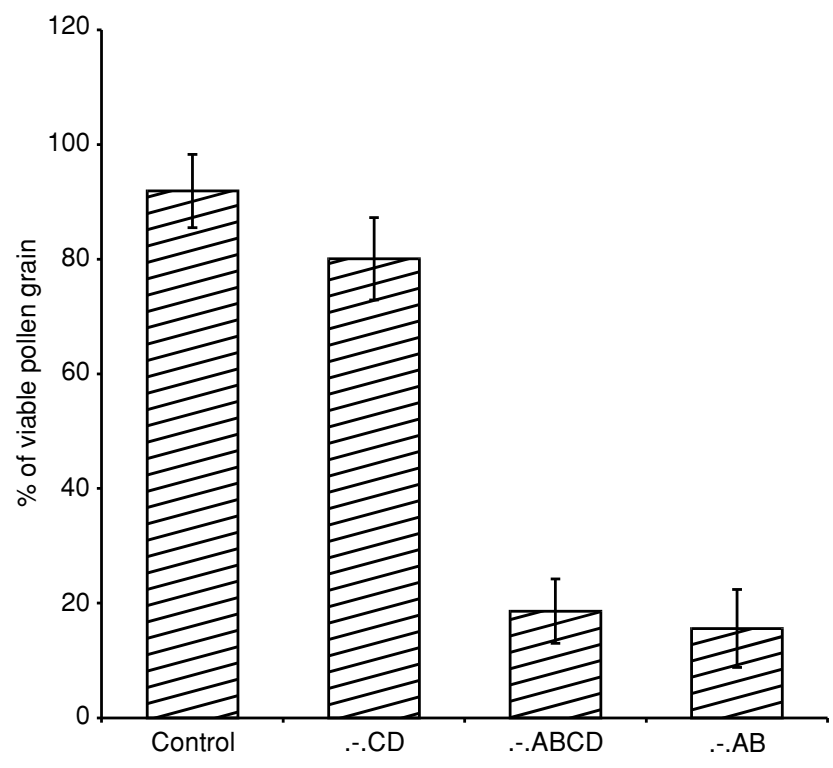

Diagram 1. Viability of mature pollen grains in control plants and in plants with different proportions of histone $\mathrm{H} 1$.

\section{Tobacco plants with different levels of H1 histone variants}

Generally speaking, tobacco plants having various levels of H1 variants show similar correlations of length of the flower bud and the developmental phase of the male gametophyte as in the control.

Early archesporial and archesporial stages (5- and $6 \mathrm{~mm}$ long buds)

In the early stages of development, i.e., both in the early archesporial $(5 \mathrm{~mm})$ and in the archesporial $(6 \mathrm{~mm})$ phase, the anthers of the plants with particular $\mathrm{H} 1$ histone variants removed, had the same structure as in the control. All the parietal layers were distinctly formed, and every pollen sac was filled with strongly basophil sporogenous tissue. At first, they had a meristematic character; then they became shaped like a croissant. Similarly to the control, in which the course of meiosis was thoroughly regular, the sporogenous tissue cells at the development stage entered the zygotene of the I meiotic prophase. On their surface, a thin layer of callose began to be deposit.

\section{Meiotic stage (7-8 mm-long bud)}

In anthers of this stage, the sporogenous tissue cells were in the middle of their meiotic divisions. However, unlike in the control, the meiosis was asynchronous in the particular variants of those plants. A detailed analysis of the meiotic division asynchrony in particular variants of those plants was carried out in preparations squashed in acetoorcein. On that basis, and on the basis of observation of semi-thin sectioned preparations, it has been determined that the most asynchronous course of meiosis was found in two variants: $-\mathrm{AB}$ and $-\mathrm{ABCD}$ (Diagram 2). The asynchrony was observed both within the pollen sacs and in the anthers within a bud. Apart from the meiocytes phase in stage I meiotic division, the same pollen sac contained meiocytes in phase II of the meiotic division (Fig. 9). Moreover, during the meiotic division, mainly in plants of the $-\mathrm{AB}$ and $-\mathrm{ABCD}$ variants, numerous chromosome aberrations were observed (lost chromosomes, ana- and telophase bridges) (Diagram 3). In plants of the -CD group, meiosis did not have such an asynchronous character and was as regular as in the control group. There were also no significant differences in the meiocyte ultrastructure in comparison with the control. Similarly all the meiocytes were enveloped in a thick callose layer.

\section{Tetrad stage (9 mm-long bud)}

In the pollen sacs of $9 \mathrm{~mm}$-long buds of the plants with $\mathrm{H} 1$ variants removed $(\mathrm{AB}, \mathrm{ABCD}$ and $\mathrm{CD})$ similarly as in the control, mainly microspore tetrads were found, although also meiocytes at earlier meiosis stages were observed (Fig. 10). The tetrads themselves had often an abnormal appearance (irregular, not separated, mace-shaped, poliads, dyads) (Figs. 11, 12), which was a result of the disturbances observed at the earlier stages of meiosis. These disturbances were much more common in plants with no $\mathrm{AB}$ or ABCD variants (Diagram 3). Their cytoplasm was also much more vacuolated and the organelles less active in comparison with the tetrads of $-\mathrm{CD}$ and control plants.

In plants lacking the $\mathrm{CD}$ variants, tetrads were formed in a typical way, as in the control. However, occasionally, smaller microspores with symptoms of degeneration were found (Fig. 13). Microspore tetrads, both normal and chan- 

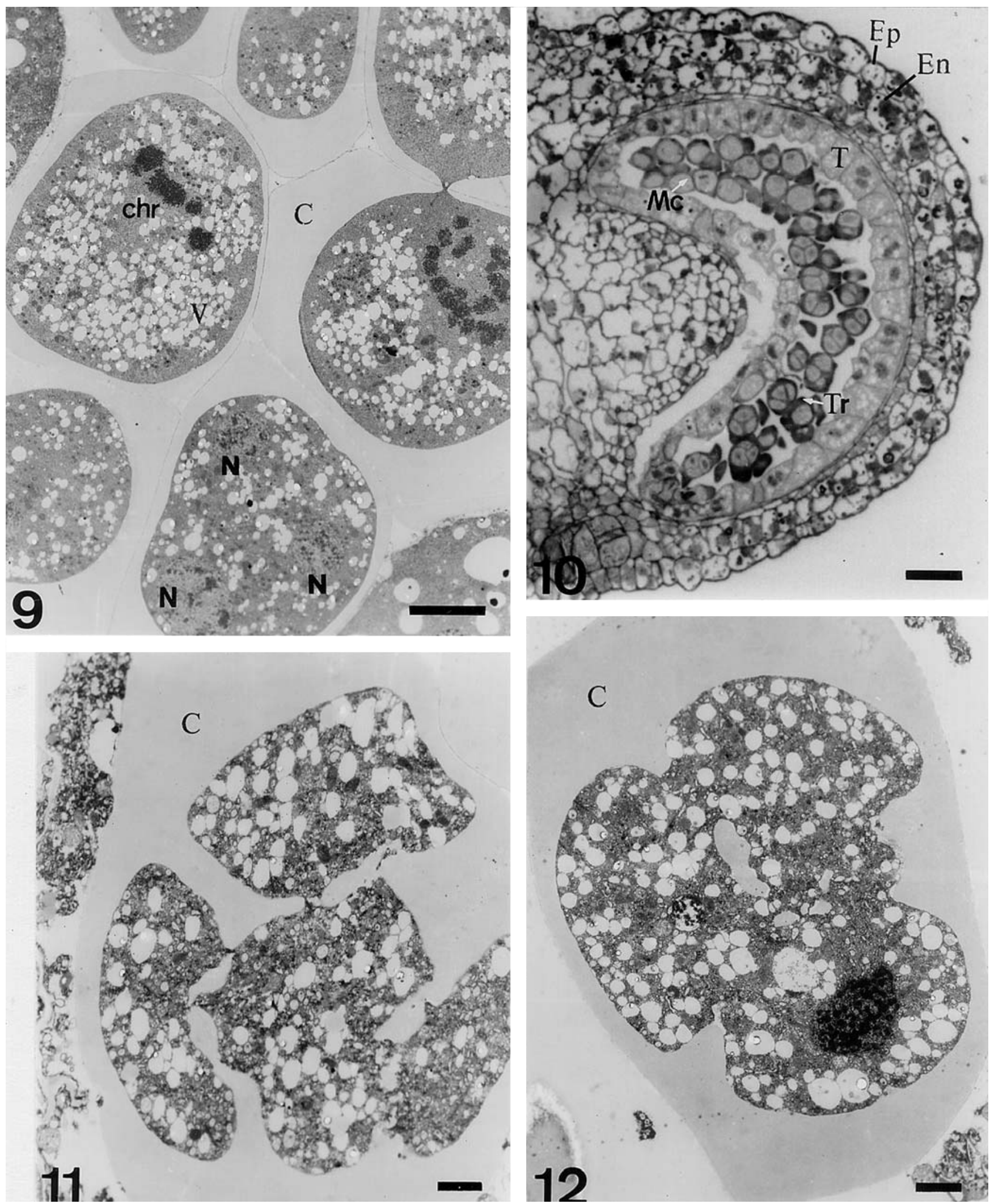

Figs 9-12. Microsporogenesis and atypical tetrads in plants with altered proportions of histon $\mathrm{H} 1$ variants.

Fig. 9. $-\mathrm{AB}$ plant's meiocytes in different stages of the meiotic division. At the bottom there is a meiocyte in the II telophase, at the right - in the I telophase and at the left - in the meiotic metaphase. Bar $=2 \mu \mathrm{m}$.

Fig. 10. The $-\mathrm{AB}$ plant's pollen sack in the plane of section. All wall layers of the sack are visible: epidermis (Ep), endothecium (En), middle layers (ML), tapetum $(\mathrm{T})$. In the sack there are tetrads of microspores and meiocytes in different stages of the meiotic division (asynchrony). Bar $=3 \mu \mathrm{m}$.

Fig. 11. The inregular tetrad of $-\mathrm{AB}$ plants microspores, made as a result of disturbed cytokinesis. $\mathrm{Bar}=1 \mu \mathrm{m}$.

Fig. 12. The $-\mathrm{AB}$ plant's inseparable tetrad of microspores in surrounding callose. Bar $=1 \mu \mathrm{m}$. 


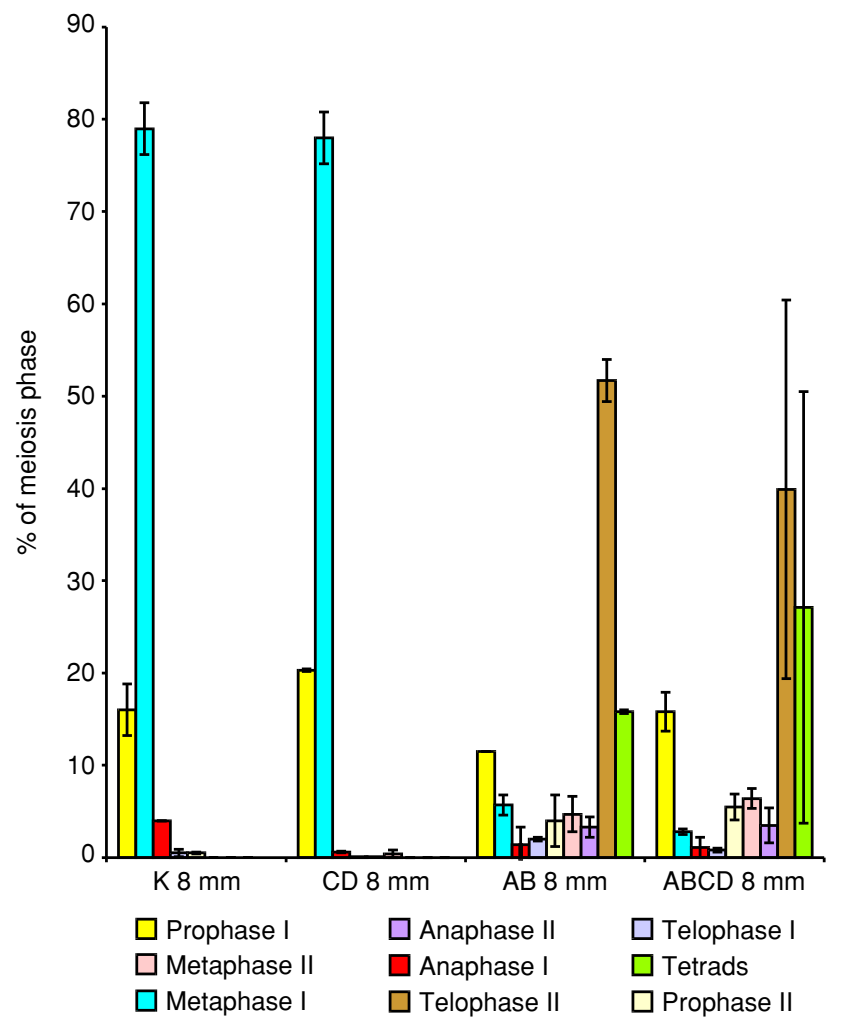

Diagram 2. Meiosis phase index in control plants $(\mathrm{K})$ and in plants with different proportions of histone $\mathrm{H} 1$.

ged, were surrounded by a callose envelope similarly to the control. In some pollen sacs, sporoderm started to deposit around the microspores, and the callose wall became hydrolysed. That process, unlike in the control, was not synchronous in a tetrad, especially in plants lacking the $\mathrm{AB}$ and $\mathrm{ABCD}$ variants (Fig. 14).

\section{Microspore stage (10 mm-long bud)}

In a pollen sac of that stage, as in the control, microspores were loosely packed and mononucleate. In all the combinations degraded microspores occurred (Fig. 15). They were most numerous in plants with the $A B$ and $A B C D$ variants of the $\mathrm{H} 1$ histone removed. They had irregularly swollen sporoderm, forming in some places a very thick layer or aggregations of irregular appendices and „droplets” in the place of a future pore. Some of the microspores did not produce sporoderm at all, although their cytoplasm was vacuolated and the nucleus had moved towards the cell wall (Fig. 16). The cytoplasm of the microspores surrounded by the irregularly thickened wall was strongly degraded; also the organelles in it showed symptoms of destruction. In some microspores, it was dispersed in the form of irregular floccules and contained a degrading embryo, in other ones it was strongly shrunk and very dense (Fig. 16). The microspores of a normal appearance were similar to the control ones in all combinations. They had cytoplasm with small vacuoles and numerous organelles (plastids, mitochondria, ER), and contained a large centrally located nucleus.

\section{Vacuolated microspores stage (14 mm-long bud)}

At the next developmental stage, the pollen sacs contained mononucleate vacuolated micropores. In plants from the $-\mathrm{AB}$ and $-\mathrm{ABCD}$ groups, many of them had an irregu-

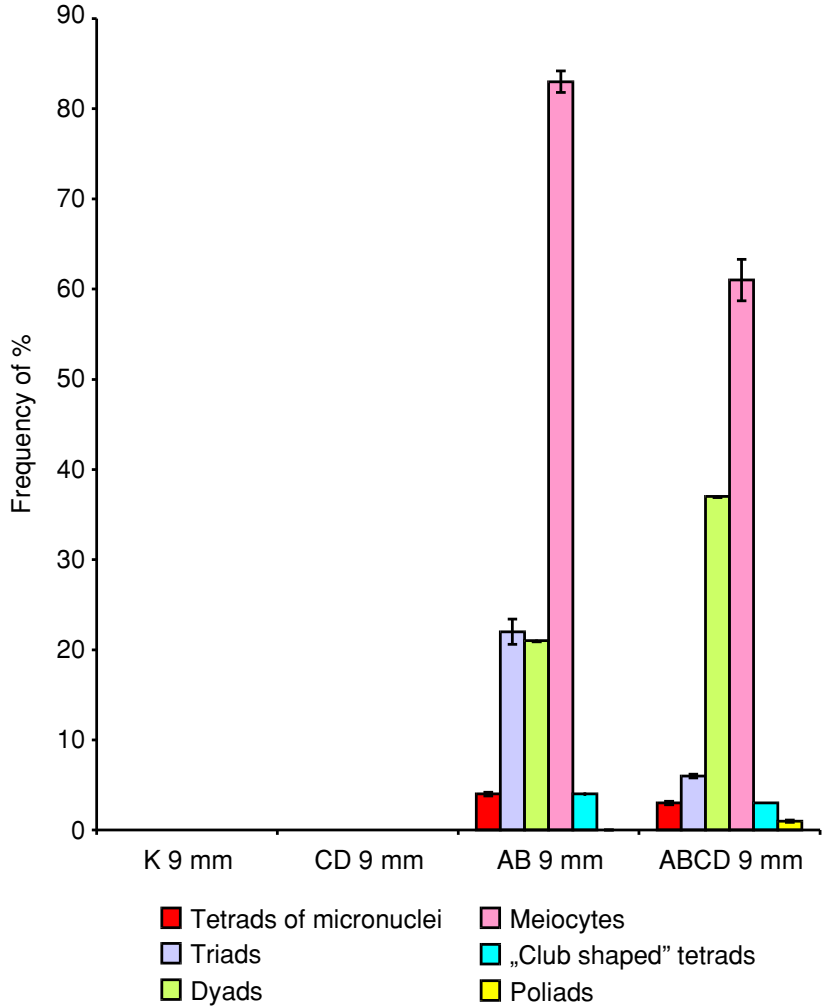

Diagram 3. Frequency of atypical tetrads and meiocytes in control plants and in plants with different proportions of histone $\mathrm{H} 1$.

lar shape, and their sporoderm was of irregular thickness. Sometimes, the microspore nucleus showed initial symptoms of degradation (Fig. 17).

Degraded microspores were much fewer in the $-\mathrm{CD}$ group, and their percentage corresponded with the number of dead pollen grains as observed at later stages (Diagram 1). In their cytoplasm, electron-dense lipid bodies were occasionally seen.

\section{Immature pollen grains stage (16 mm-long bud)}

At this stage, two-celled pollen grains, built of a vegetative cell and a parietally located generative cell, were observed. Such pollen grains prevailed in the control and in the $-\mathrm{CD}$ group. In the $-\mathrm{AB}$ and $-\mathrm{ABCD}$ groups, degraded pollen grains of an irregular shape prevailed (Diagram 1). They usually had a single, centrally located nucleus in rarefied cytoplasm, containing remainders of degraded organelles (Fig. 20). Both their exine and intine layers were irregularly thickened. Additionally, in the $-\mathrm{ABCD}$ combination, the cytoplasm of the vegetative and generative cell contained numerous starch grains and grey homogeneous lipid structures (Fig. 19).

In the $-\mathrm{CD}$ combination, considerably more pollen grains had a normal appearance. Their cytoplasm contained many starch grains and grey lipid bodies. Among the pollen grains, few microspores in the initial phase of vacuolation were observed. Some of them were enveloped in a comparatively thin sporoderm, with a scant intine layer (Fig. 19, Diagram 1).

\section{Mature pollen grains stage $(45 \mathrm{~mm})$}

At this stage, in all the variants of plants, mature pollen grains, consisting of a vegetative and a generative cell, separated from the sporoderm, were found, with different 

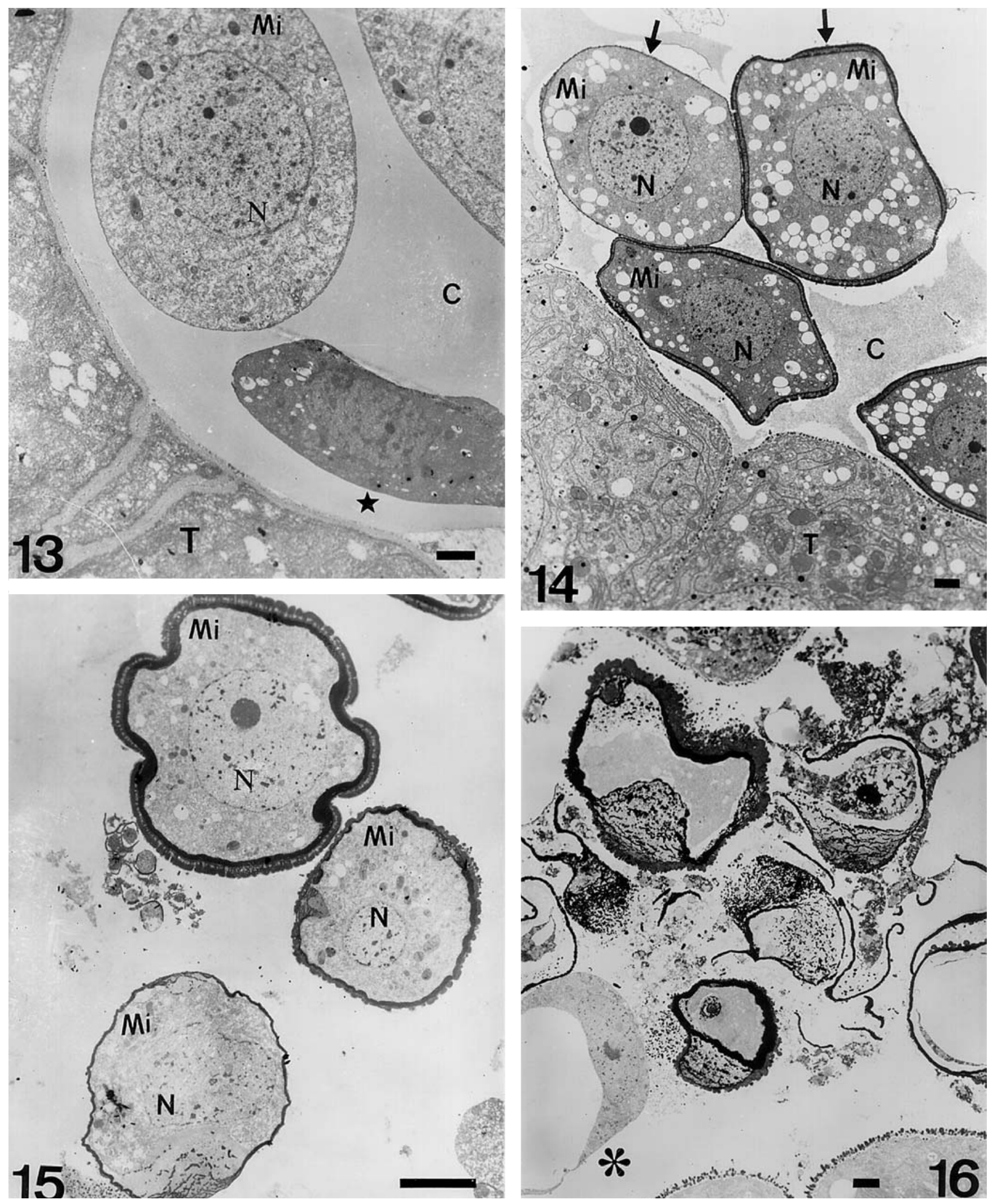

Figs 13-16. Tetrads and microspores in plants with altered proportions of histon $\mathrm{H1}$ variants. Bars $=\mathbf{2} \boldsymbol{\mu m}$.

Fig. 13. The $-\mathrm{CD}$ plant's tetrad of microspores in surrounding callose. At the bottom there is a smaller degenerative microspore (star).

Fig. 14. The callose hydrolysis in the $-\mathrm{AB}$ plant's tetrad of microspores. On the surface of microspores at the different rate accumulates a sporoderm.

Fig 15. The -ABCD plant's onenuclear microspores. A normal microspore surrounded by a sporoderm, below there are two smaller microspores surrounded by a thiner and atypically formed sporoderm.

Fig. 16. The -ABCD plant's degraded microspores surrounded by a sporoderm of a heterogeneous thickness; at the bottom there is a vacuolated microspore (star) which did not create a sporoderm. 

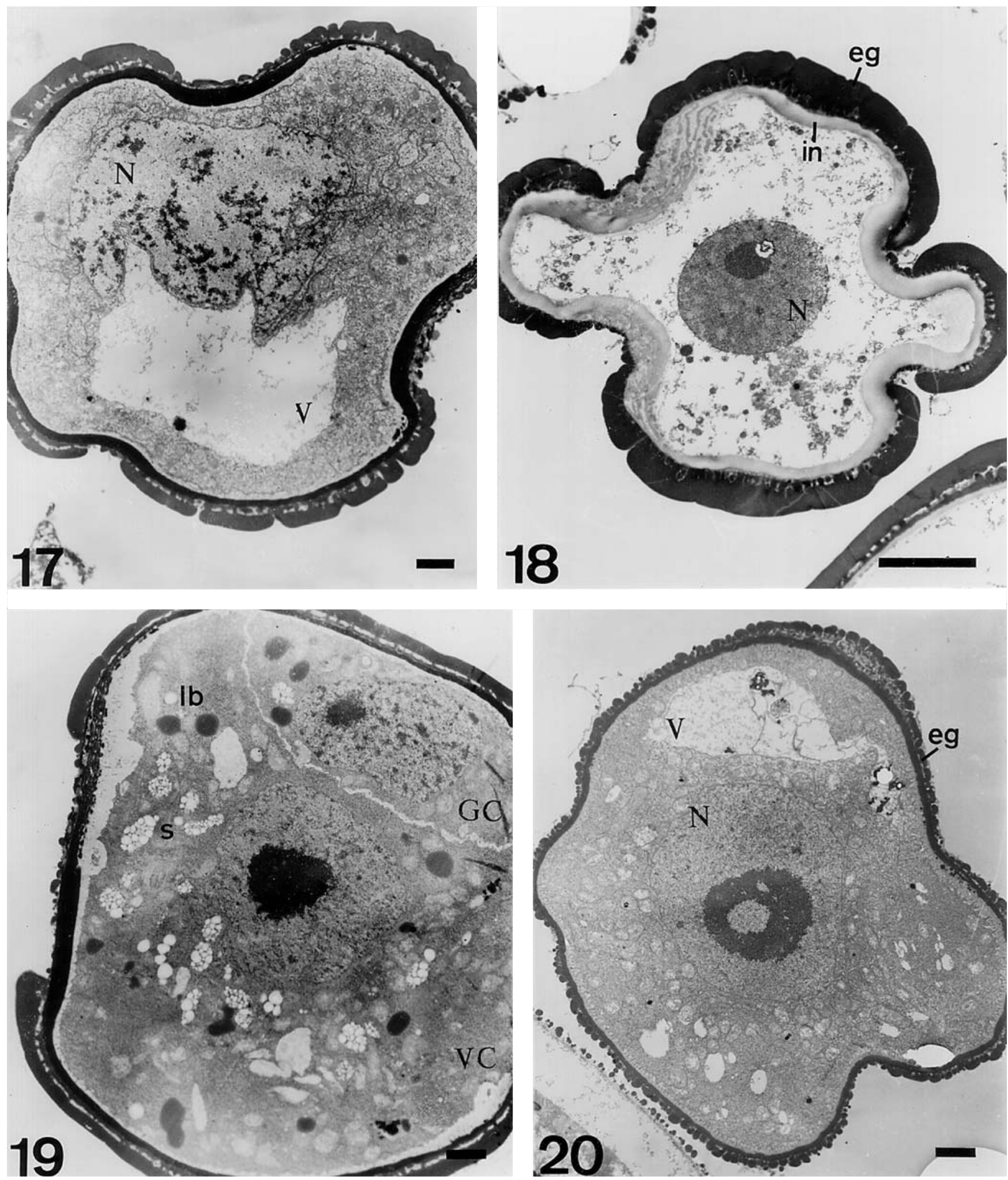

Figs 17-20. Microspores and pollen grains in plants with altered proportions of histon H1 variants. Bars = $2 \mu \mathrm{m}$.

Fig. 17. The $-\mathrm{ABCD}$ plant's onenuclear microspore during vacuolation. A nuclear indicates signs of degeneration.

Fig. 18. The $-\mathrm{AB}$ plant's onenuclear microspore during degeneration in a surrounding thick sporoderm differentiated on exine (eg) and intine (in). In a very weakend cytoplasm, a central situated nuclear is visible.

Fig. 19. The -ABCD plant's bicellular pollen grains. In the vegetative and generative cells, starch grains (s) and lipid bodies (lb) are visible.

Fig. 20. The -CD plant's onenuclear microspore during vacuolation in a surrounding thin exine layer.

percentages of degraded pollen grains (Diagram 1). The highest number of abnormal pollen grains was found in the $-\mathrm{AB}$ group (84.4\%) (Fig. 18) and -ABCD group (81.4\%). The fewest abnormal pollen grains were found in the $-\mathrm{CD}$ group (-19.9\%) (Diagram 1). However, the cytoplasm of their vegetative cells contained a rather high number of grey-and-black lipid structures and starch grains (see the previous stage). In many small vacuoles, black phenolic aggregations were observed. Such changes were not found in the control group (Fig. 8). 


\section{DISCUSSION}

The investigation into mechanism of $\mathrm{H} 1$ histone action, which has been carried out for several years, has shown that elevation of the level of its small variants in comparison to the main variants induces major phenotype changes in the cells, leading to disturbances in the development of flower and male sterility. There is evidence that the reason for such changes are defects in the pairing of homologous chromosomes and their proper separation during meiosis (Prymakowska-Bosak et al. 1999; Ślusarczyk et al. 2001a and $b$ ).

Similar phenotype changes in the development of the male gametophyte occurred in plants with particular variants of the $\mathrm{H} 1$ histone set out. A comparison of all the three variants allows them to be divided into two groups. The first group consists of plants lacking the $\mathrm{AB}$ and $\mathrm{ABCD}$ variants, showing stronger changes connected with asynchronous meiotic divisions and numerous chromosomal aberrations. It can be speculated that the degradation observed in the development of the male gametophytes of those plants is a consequence of the disturbances in their meiotic divisions. The other group consists of plants lacking the $\mathrm{CD}$ variants, showing few changes and a regular course of meiosis, similarly as in the control. The changes were not observed, and the number of degraded pollen grains was smaller (Diagram 1).

The disturbances in meiosis, leading to male sterility, were also observed in barley (Skazkin and Zavadskaya 1957) and wheat (Saini and Aspinall 1981) under the stress of drought. The microspores formed after such stress seemed to be normal; however, their further development was gradually inhibited and many sterile pollen grains were formed. In the early stages of flower development, during the meiotic divisions in the sporogenous tissue, plants are especially susceptible to various stress conditions, including drought (Saini 1997). It is believed that one signal for the induction of male sterility as a response to the stress of drought is an elevated level of sucrose in the cells; however, the molecular mechanism for such a dependence is unknown. The results of biochemical analyses have given some explanations. It has been found, that the two minor variants of the $\mathrm{H} 1$ histone (H1C and H1D), the level of which is increased in male-sterile plants $(-\mathrm{AB})$, belong to plant variants of $\mathrm{H} 1$ induced by drought, and they contain a sequential element involved in the reaction to the level of sucrose in the cells (Przewłoka et al. 2002). However, the lack of reversion of male sterility phenotypes in -ABCD cells indicates that the elevation of drought-induced variants $(\mathrm{C}$ and $\mathrm{D})$ itself is not an immediate reason for sterility in tobacco. Moreover, in $-\mathrm{CD}$ and $-\mathrm{ABCD}$ plants, grey-and-black lipid structures and starch grains were found in the cytoplasm of vegetative cells in normal-looking pollen grains, which may indicate some disturbances in their metabolism. Thus, it seems that the most important factor is a change in the proportions between the major and the minor variants, consisting in the reduction of the major ones.
Undoubtedly, the metabolism of carbohydrates is important for regulation of the microporogenesis process in plants. It is possible that the molecular grounds for the phenotype induced by drought, typically seen in plants, comprise induction of transcription or selective stabilisation of mRNA of specific variants of the $\mathrm{H} 1$ histone, and, as a consequence, a change in the normal proportions of the $\mathrm{H} 1$ variants in chromosomes, leading to the disturbances in the identification and pairing of homologous chromosomes during meiosis, as well as causing the production of infertile gametes.

\section{LITERATURE CITED}

ASCENZI R., GANTT J.S. 1997. A drought-stress-inducible histone $\mathrm{H} 1$ gene in Arabidopsis thaliana is a member of a distinct class of plant linker histones. Plant. Mol. Biol. 34: 629-641.

ASCENZI R., GANTT J.S. 1999. Subnuclear distribution of the entire complement of linker histone variants in Arabidopsis thaliana. Chromosoma 108: 345-355.

PRYMAKOWSKA-BOSAK M., PRZEWŁOKA M., IWKIEWICZ J., EGIERSZDORFF S., KURAŚ M., CHAUBET N., GIGOT C., SPIKER S., JERZMANOWSKI A. 1996. Histone $\mathrm{H} 1$ overexpressed to high level in tobacco affects certain developmental programs but has limited effect on basal cellular functions. Proc. Natl. Acad. Sci. USA 93 10250-10255.

PRYMAKOWSKA-BOSAK M., PRZEWŁOKA M., ŚLUSARCZYK J., KURAŚ M., LICHOTA J., KILIAŃCZYK B., JERZMANOWSKI A. 1999. Linker histones play a role in male meiosis and the development of pollen grains in tobacco. Plant Cell 11: 2317-2329.

PRZEWŁOKA M.R., WIERZBICKI A.T., ŚLUSARCZYK J., KURAŚ M., GRASSER K.D., STEMMER C., JERZMANOWSKI A. 2002. The „drought-inducible” histone H1s of tobacco play no role in male sterility linked to alterations in H1 variants. Planta. 215: 371-379.

REYNOLDS E.S. 1963. The use of lead citrate at high $\mathrm{pH}$ as an electron opaque stain in electron microscopy. J. Cell Biol. 17: 208-212.

SAINI H.S., ASPINALL D. 1981. Effect of water deficit on sporogenesis in wheat (Triticum aestivum L.). Ann. Bot. 48: 623-633.

SAINI H.S. 1997. Effects of water stress on male gametophyte development in plants. Sex. Plant Reprod. 10: 67-73.

SKAZKIN F.D., ZAVADSKAYA I.G. 1957. On the influence of soil moisture deficiency and nitrogen nutrition on microsporogenesis in barley. Ibid. 117: 240-242.

STANLEY R.G., LINSKENS H.F. 1974. Pollen-biology, biochemistry, management. Springer, Berlin Heidelberg New York, pp. 307.

ŚLUSARCZYK J., PRYMAKOWSKA-BOSAK M., PRZEWŁOKA M., JERZMANOWSKI A., KURAŚ M. 2001. Disorders of microsporogenesis in transgenic tobacco plants with altered proportions of native histone $\mathrm{H} 1$ variants. Acta Biol. Crac. Ser. Bot. 43: 69-78.

ŚLUSARCZYK J., PRYMAKOWSKA-BOSAK M., PRZEWŁOKA M., JERZMANOWSKI A., KURAŚ M. 2001. Disturbances of pollen development in tobacco plants with low level of histone H1. Biol. Bull. Poznań. 38: 55-61.

WEI T., O'CONELL M.A. 1996. Structure and characterization of a putative drought-inducible H1 histone gene. Plant. Mol. Biol. 30: 255-268. 


\section{WPŁYW ZMIANY PROPORCJI WARIANTÓW HISTONU H1 NA MIKROSPOROGENEZĘ I ROZWÓJ MĘSKIEGO GAMETOFITU W TRANSGENICZNTCH ROŚLINACH TYTONIU (NICOTIANA TABACUM L.)}

\section{STRESZCZENIE}

Kontynuując badania nad mechanizmem działania histonu H1, kluczowego składnika białkowego chromosomów wszystkich organizmów eukariotycznych, analizowano transgeniczne rośliny tytoniu z różnym poziomem wariantów histonu H1. Tytoń posiada sześć wariantów sekwencyjnych histonu H1: dwa duże (H1A i H1B) stanowiące około 90\% wszystkich H1 i cztery małe (H1C, H1D, H1E i H1F) występujące w śladowych ilościach. Badano następujące grupy roślin: $\mathrm{K}$ - grupa kontrolna z pełnym składem wariantów histonowych, $-\mathrm{AB}$ - z wyłączonymi wariantami A i B, $-\mathrm{ABCD}-\mathrm{z}$ wyłączonymi wariantami A, B, C i D oraz $-\mathrm{CD}-\mathrm{z}$ wyłączonymi wariantami C i D.

Analiza mikrosporogenezy u tych roślin, wykonana w oparciu o preparaty gniecione w acetoorceinie, ujawniła asynchroniczny przebieg mejozy w roślinach $-\mathrm{AB}$ oraz $-\mathrm{ABCD}$, występowanie aberracji chromosomowych i w efekcie powstawanie sterylnych ziaren pyłku (odpowiednio: 84,4\% oraz 81,4\%). W roślinach -CD procent aberracji i sterylnych ziaren pyłku był zbliżony do poziomu materiału kontrolnego. Obserwacje mikrosporogenezy w mikroskopie elektronowym wykazały występowanie zmian na poziomie ultrastrukturalnym. W przypadku roślin z wyłączonymi wariantami AB oraz ABCD powstające ziarna pyłku były w znacznej części zdegradowane. Najmniej zdegradowanych ziaren pyłku w stosunku do kontroli obserwowano u roślin z wyłączonymi wariantami CD.

SŁOWA KLUCZOWE: Nicotiana tabacum L., warianty histonu H1, zaburzenia mikrosporogenezy, sterylne ziarna pyłku. 